\title{
Distribution and concentration of cadmium in root tissue of Populus alba determined by scanning electron microscopy and energy- dispersive $\mathrm{x}$-ray microanalysis
}

\author{
Cocozza C ${ }^{(1)}$, Minnocci A ${ }^{(2)}$, Tognetti $R^{*(1)}$, Iori $V^{(3)}$, Zacchini $M^{(3)}$, \\ Scarascia Mugnozza G ${ }^{(3)}$
}

In a polluted environment with potentially toxic elements, plants may play a relevant role on contaminant absorption or stabilization. The aim of this study was to discriminate two poplar clones in their tolerance to high Cd concentrations $(50 \mu \mathrm{M})$ in the growth solution and to show the potential of poplar in the cleaning-up of Cd-contaminated substrate. Chemical analyses to determine the content of heavy metals in biological samples involve their destruction by digestion with concentrated acids, preventing the localization of potentially toxic elements in situ. In contrast, scanning electron microscopy equipped with energy-dispersive $\mathrm{x}$-ray microanalysis may provide information on element localization and chemical composition of biological samples. Scanning electron microscopy allows for the observation of samples in a dry or wet state, at high magnifications and good field depth with a minimum preparation, and the possibility to combine structural and analytical information by energy-dispersive $\mathrm{x}$-ray microanalysis and digital images. Although, energy-dispersive $\mathrm{x}$-ray microanalysis has relatively low detection limits, it is useful in establishing distribution maps of potentially toxic elements inside cells and tissues. Tissue concentration and localization of Cd (and other elements) in root tips of Populus alba clones (6K3 and 14P11) were investigated, using two different types of scanning electron microscope (ambient temperature and low temperature) both coupled with energy-dispersive $x$-ray microanalysis. These techniques were useful to investigate structural modifications and to identify in situ concentration and distribution of $\mathrm{Cd}$ in poplar roots, establishing indirect correlations between accumulation and localization of the metal. Overall, observations suggested differential patterns between 6K3 and 14P11 clones in accumulating $\mathrm{Cd}$ within the root profile, though overall concentration and content of $\mathrm{Cd}$ in the root system, determined by atomic absorption spectrophotometry, did not differ between clones. The possibility that these accumulation patterns arise from differences in uptake processes and structural properties is discussed and related to tolerance mechanisms.

Keywords: EDXMA, heavy metals, poplar, pollution, SEM

\begin{abstract}
${ }^{(1)}$ EcoGeoFor Lab - Dipartimento di Scienze e Tecnologie per l'Ambiente e il Territorio, Università degli Studi del Molise, Contrada Fonte Lappone, I-86090 Pesche (IS, Italy); (2)BioLabs, Scuola Superiore Sant'Anna, v.le Rinaldo Piaggio, I-56025 Pontedera (PI, Italy); ${ }^{(3)}$ IBAF-CNR, v. Salaria, I-00016 Monterotondo Scalo (RM, Italy).

*Corresponding Author: Roberto Tognetti (tognetti@unimol.it).
\end{abstract}

Received: Oct 12, 2007 - Accepted: Jan 16, 2008

Citation: Cocozza C, Minnocci A, Tognetti R, Iori V, Zacchini M, Scarascia Mugnozza G, 2008. Distribution and concentration of cadmium in root tissue of Populus alba determined by scanning electron microscopy and energy-dispersive $\mathrm{x}$-ray microanalysis. iForest 1: 96-103 [online: 2008-05-19] URL: http://www.sisef.it/iforest/

\section{Introduction}

Heavy metal accumulation in plants is often restricted to the root tissue, with only small amounts transported to the shoot (Taylor 1987). An understanding of the toxicologic and physiologic responses of Populus to heavy metals is of particular relevance when attempting to predict the impact of ions on multipurpose tree plantations. This is particularly important when studying metal effects in contaminated riparian ecosystems receiving large quantities of cation laden domestic and industrial wastes. Researches have been conducted on the use of poplar trees for the extraction (phytoremediation) or immobilization (phytostabilization) of heavy metals in polluted sites (Punshon \& Dickinson 1997, Schnoor 1999, Koprivova et al. 2002). In addition, Populus are currently grown for pulpwood and as a renewable energy source (Moffat et al. 2001). However, studies of heavy metal absorption and accumulation in poplar trees are limited, as are investigations on physiological responses and the basis of poplar tolerance to these elements, and mechanisms of their detoxification (Arisi et al. 2000, Di Baccio et al. 2005). Trace elements are defined as chemicals with low concentrations in plant tissues (lower than $0.1 \%$ ), independent of their toxicity or nutritional value. Heavy metals such as $\mathrm{Cd}$ are not essential and are also highly toxic (Küpper et al. 2000). Cadmium is a relatively rare element with undetermined biologic function (Sunda 1990). It is considered to be one of the most hazardous trace elements in the environment because of its high toxicity to all components of aquatic communities (Vymazal 1987). Cadmium has received widespread attention because of its accelerated release into the environment as the result of industrial pollution (Surosz \& Palinska 2004). The phytotoxicity of $\mathrm{Cd}$ is well known (e.g., Van Assche \& Clijsters 1990) and is manifested as inhibition of plant growth (Titov et al. 1995), nitrate assimilation (Hernández et al. 1997) and photosynthesis (e.g., Barceló et al. 1988), as well as disturbances in plant ion (Wallace et al. 1992) and water balances (Barceló \& Poschenrieder 1990). Many of these plant responses to heavy metals are a result of the inhibition of enzymatic activity caused by the binding of heavy metal ions to sulfhydryl groups in the active sites of enzymes and by substitution of essential metals (Van Assche \& Clijsters 1990).

In particular, Cd may interfere with the uptake of positively charged ions in plant roots (Walker et al. 1977) and with element translocation to the shoot (Lamoreaux \& Chaney 1977). Plants have developed different tolerance strategies to grow on soils rich in heavy metals (Baker 1981, Baker et al. 2000). "Excluders" have a low uptake of trace elements, by active exclusion in the root system, even at high external concentrations in the soil solution. "Accumulators" are able to tolerate high concentrations of trace elements in their tissues, and this accumulation can be produced even at low external concentrations in the soil solution. "Indicators" have a relatively constant root uptake over a wide gradient of trace elements in the soil. Driven by the potential of their use to extract and remove (or stabilize) toxic metals from contaminated soils (Salt et al. 1998), there has been recent progress in our understanding of the uptake, translocation and compartmentation of heavy metals in poplars (e.g. Di Baccio et al. 2003, Sebastiani et al. 2004, Tognetti et al. 2004, Borghi et al. 2007).

Little is known about the physiology of in- 
tracellular $\mathrm{Cd}$ sequestration in poplars. There are different methods for determining elements distribution in plant tissues such as histochemical (Vázquez et al. 1992b, Seregin \& Ivanov 1997), cell fractionation (LozanoRodríguez et al. 1997), x-ray microanalysis (Khan et al. 1984, Vázquez et al. 1992a, Vázquez et al. 1992b), particle-induced x-ray emission (micro-PIXE - Ager et al. 2002) or nuclear micro-probe technique (NMP - Ager et al. 2003). Although not always useful at very low metal concentrations, x-ray microanalysis provides specific signals compared to other methods (Wójcik et al. 2005 et al. 2005). In the present work we used x-ray microanalysis to determine tissue localization and concentration of $\mathrm{Cd}$ in root tips of Populus alba clones (6K3 and 14P11).

These genotypes from contrasting environments were compared under salt stress conditions by measurement of growth, $\mathrm{Na}$ accumulation, and expression of PM-ATPase and V-ATPase genes in leaves of control and salt-stressed plants (Beritognolo et al. 2007) The different response to salinity showed by these clones was related to a different ability in excluding $\mathrm{Na}$ at the root level and to a different regulation of ion transport across membranes in leaf cells, which could be the expression of adaptation to ecological conditions of original provenances. A different genetic basis was supposed to underlie the different degree of salt tolerance observed Knowledge of Cd distribution in white poplar roots of various clones may help to understand some mechanisms of $\mathrm{Cd}$ accumulation and tolerance in this multipurpose tree species and to select for desirable genotypes White poplar has rapid growth, and is naturally found on a wide range of soil types, being relatively tolerant to pollution (Madejón et al. 2004, Fodor et al. 2005). These poplars grow on riverbanks, in south and centra Europe, Western Asia and North Africa; besides, they are widely used in urban forestry. An ancillary objective was that of comparing two different scanning electron microscope techniques in describing the distribution of $\mathrm{Cd}$ within root tissues

\section{Materials and Methods}

\section{Plant material and growth conditions}

Woody cuttings of Populus alba L. clones (6K3 and 14P11) with uniform size $(20 \mathrm{~cm}$ in length and diameter larger than $1 \mathrm{~cm}$ ) were collected from mother plants at IBAFCNR (Montelibretti - Roma, Italy). Cuttings were grown in pots suitable for hydroponic culture (diameter 13-15 mm), and supplied with third strength Hoagland nutrient solution, $\mathrm{pH}$ 6.5. After three weeks of development in the hydroponic system, 5 homogeneous plants per genotype were selected and randomly assigned to two groups of treatment; $\mathrm{Cd}$ was added as $\mathrm{CdSO}_{4}\left(\mathrm{CdSO}_{4} \cdot 4 \mathrm{H}_{2} \mathrm{O}\right.$
- Sigma, Saint Louis, USA) to the nutrient solution to give concentrations of 0 or $50 \mu \mathrm{M}$ $\mathrm{Cd}$. To avoid root necrosis, the solution was completely replaced twice a week and aerated by diffused air aeration systems. Pots were located inside a growth chamber with controlled temperature $\left(25-20{ }^{\circ} \mathrm{C}\right.$ day-night $)$ and photosynthetic photon flux density (metal halide lamps, $300 \mu \mathrm{mol} \mathrm{m} \mathrm{m}^{-2} \mathrm{~s}^{-1}$ ), and a 14-h photoperiod and $70-80 \%$ relative humidity.

After three weeks of treatment, plants were gently removed from the solution and $20 \mathrm{~mm}$ long segments of primary and secondary roots were taken from each plant and immediately plunged either in liquid $\mathrm{N}_{2}$ or in a solution of $3 \%$ glutaraldehyde $\left(0.01 \mathrm{~mol} \mathrm{l}^{-1}\right.$ phosphate buffer) for storage. Analyses were done by low or ambient temperature scanning electron microscopy, respectively.

Scanning electron microscope (SEM) and energy-dispersive $x$-ray microanalysis (EDXMA)

For low temperature SEM (Cryo-SEM) investigations frozen-hydrated root samples were mounted on an aluminium stub with Tissue-Tek. Specimens were moved to a dedicated cryo-preparation chamber (SCU 020, Bal-Tech, Balzers, Liechtenstein), freeze-fractured by a motor-driven fracturing microtome at $-120{ }^{\circ} \mathrm{C}$, surface etched for 5 min at $-80^{\circ} \mathrm{C}$ under high vacuum (lower than $\left.2 \cdot 10^{-4} \mathrm{~Pa}\right)$, sputter-coated with $10 \mathrm{~nm}$ of gold (measured by quartz thin-film monitor) in an argon atmosphere (lower than $2.2 \cdot 10^{-2}$ $\mathrm{Pa})$ to produce an electrically conductive surface. Specimens were then transferred into a cryo-stage $\left(-180{ }^{\circ} \mathrm{C}\right)$ inside a SEM (Philips 515, Eindhoven, the Netherlands) equipped with the cryo unit. The EDXMA was performed in the cryo-SEM using an acceleration voltage of $17 \mathrm{kV}$, a take-off angle of $16.5^{\circ}$ and a working distance (sample to final lens) of $12 \mathrm{~mm}$. Spectra from 0 to 20 $\mathrm{keV}$ were collected at increments of $10 \mathrm{eV}$ per channel with the electron beam focused on a spot area in the centre of selected cells. Background and element-specific peak spectra were analysed using the program EDAX DX-4 (EDAX, San Francisco, USA), which fully deconvolutes the spectra and allows the corrections for interference between elements. The results are presented as peak/background ratios percentage for $\mathrm{K}, \mathrm{Ca}$ and $\mathrm{Cd}$ elements. In addition, a two-dimensional distribution pattern was recorded by scanning the area of specimens repeatedly for $30 \mathrm{~min}$ and integrating counts for $\mathrm{K}, \mathrm{Ca}$ and $\mathrm{Cd}$ (most abundant elements) within their respective spectrum windows into dot maps. Therefore, the dot map collected provides only qualitative information of element distribution and was not sensitive in depicting small variations. Slow-scan images were digitised at $768 \times 576$ pixels (256 grey levels) and analysed with AnalySIS 2.1 (Soft-
Imaging Software GmbH, Germany). The observation of frozen-hydrated root samples by cryo-SEM enables the real highlighting of structural aspects of root features during development. Internal root structures were examined on fracture planes obtained by freeze fracturing transversally the frozen-hydrated sample.

For ambient temperature SEM investigations (ambient-SEM), root samples were fixed in $3 \%$ glutaraldehyde solution $\left(\mathrm{C}_{5} \mathrm{H}_{8} \mathrm{O}_{2}\right.$, $0.01 \mathrm{~mol} \mathrm{l}^{-1}$ phosphate buffer) to maintain protein structures and then post-fixed for $3 \mathrm{~h}$ in $1 \%$ osmium tetroxide $\left(\mathrm{OsO}_{4}\right)$ to fix proteins and lipids, and to improve the contrast of electron microscope pictures. Specimens were then rinsed in fresh buffer and dehydrated through a series of ascending ethanolwater solutions (20-30-40-60-80-95-100\%), with a last wash in acetone for a better $\mathrm{CO}_{2}$ substitution during the dehydration procedure at a pressure of 1200 bars. Afterwards, to produce an electrically conductive surface and thus prevent charging under the electron beam, root samples were critical-point dried (critical point drier K850, Emitech, Ashford, UK) before gold (SEM) or carbon (EDXMA) sputtering (sputter coater K550, Emitech, Ashford, UK) under vacuum; carbon was used instead of metal coating to avoid interference with measured elements, while gold was used to improve conductivity and increase topographic contrast. Observations were done in a SEM (Zeiss DSM 940A, LEO Elektronenmikroskopie GMbH, Oberkochen, Germany) operating at $10 \mathrm{kV}$.

\section{Determination of $C d$ content}

Root samples for $\mathrm{Cd}$ determination were dried at $105{ }^{\circ} \mathrm{C}$ and wet digested in $\mathrm{HNO}_{3}: \mathrm{HClO}_{4}(4: 1, \mathrm{v} / \mathrm{v})$. The content of $\mathrm{Cd}$ was determined by atomic absorption spectrophotometry (Perkin Elmer 3300, Norwalk, USA).

\section{Statistical analysis}

The experiment was set up in a completely randomised design with five replicate plants for each treatment $(n=5)$. Data were averaged on a plant basis and subjected to analysis of variance (ANOVA) to test significant differences between the main effect of genotype, treatment and interaction terms. The Student's $t$-test (pairwise) was used to compare Cd concentration means for the two clones. Significant effects were considered at $P \leq 0.05$.

\section{Results and Discussion}

Internal and external characteristics of primary and secondary roots were not strongly affected by the treatment with $\mathrm{Cd}$ (Fig. 1A, B, C, D and Fig. 2A, B, C, D; ambient-SEM), despite the fact that the metal was found dispersed throughout all root tissues. Indeed, no major cell shrinkage or tis- 

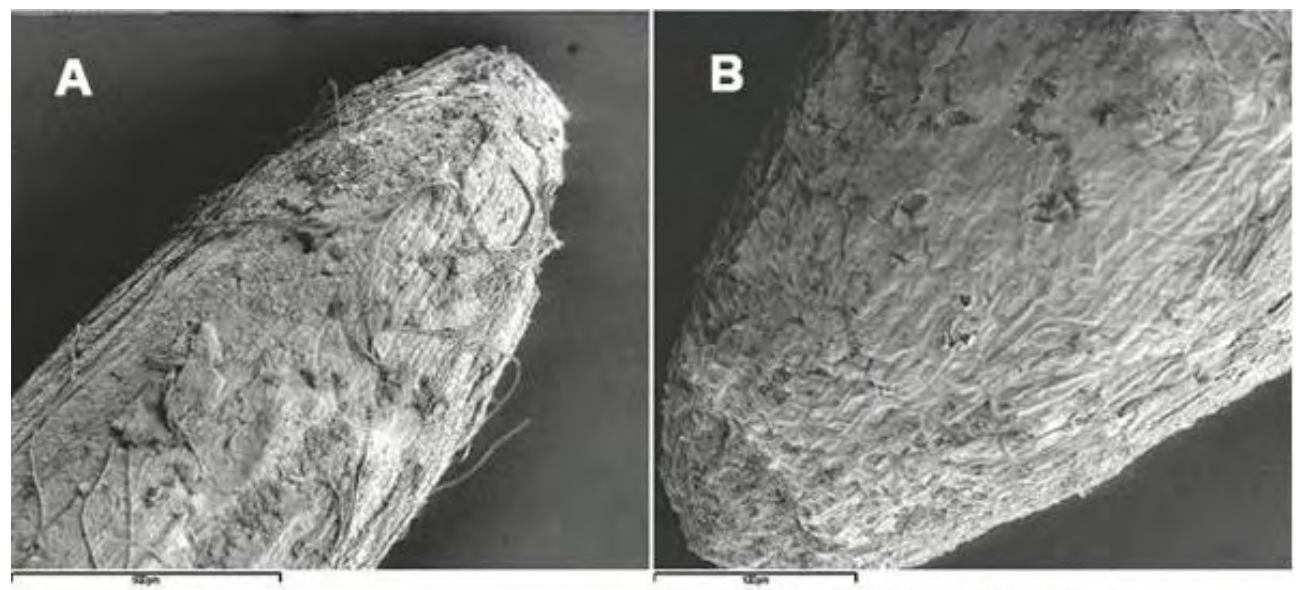

Fig. 1 - Cryo-scanning electron micrographs of poplar roots, clone 14P11: A, primary root apex (control); B, secondary root apex (treated with $\mathrm{Cd}$ ), C primary root cross-section (treated with $\mathrm{Cd}$ ); $\mathrm{D}$, root hairs (treated with $\mathrm{Cd}$ ).
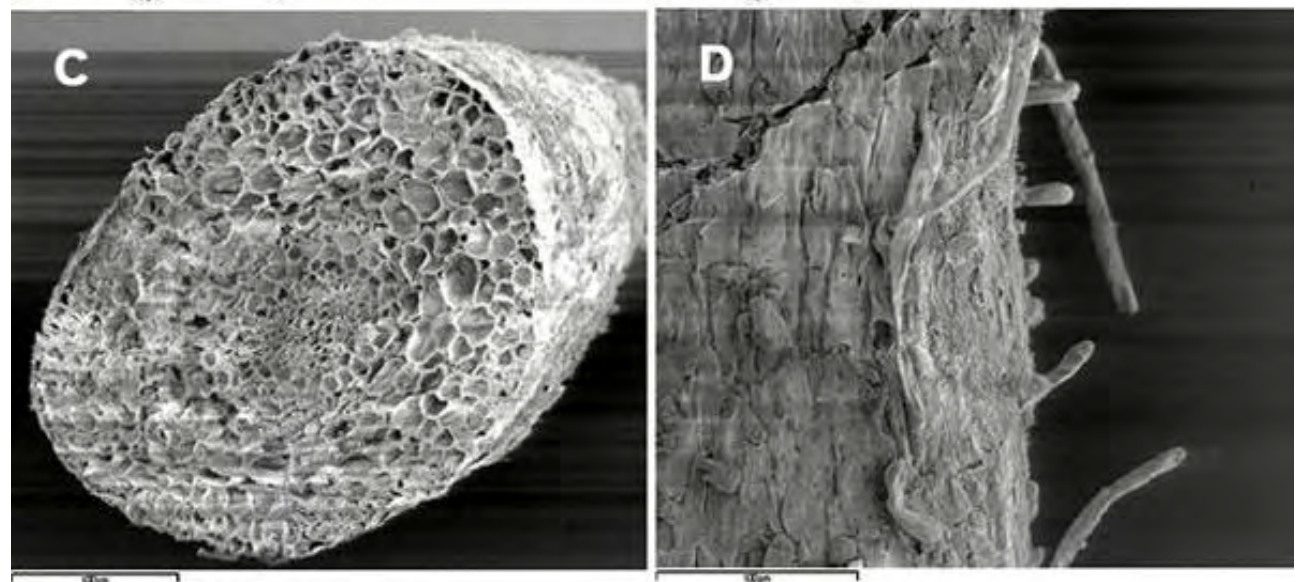

Fig. 2 - Cryo-scanning electron micrographs of poplar roots, clone $6 \mathrm{~K} 3$ : A, primary root apex (control); B, secondary root apex (treated with

Cd), C secondary root cross-section (treated with $\mathrm{Cd}$ ); D, root hairs (treated with $\mathrm{Cd}$ )
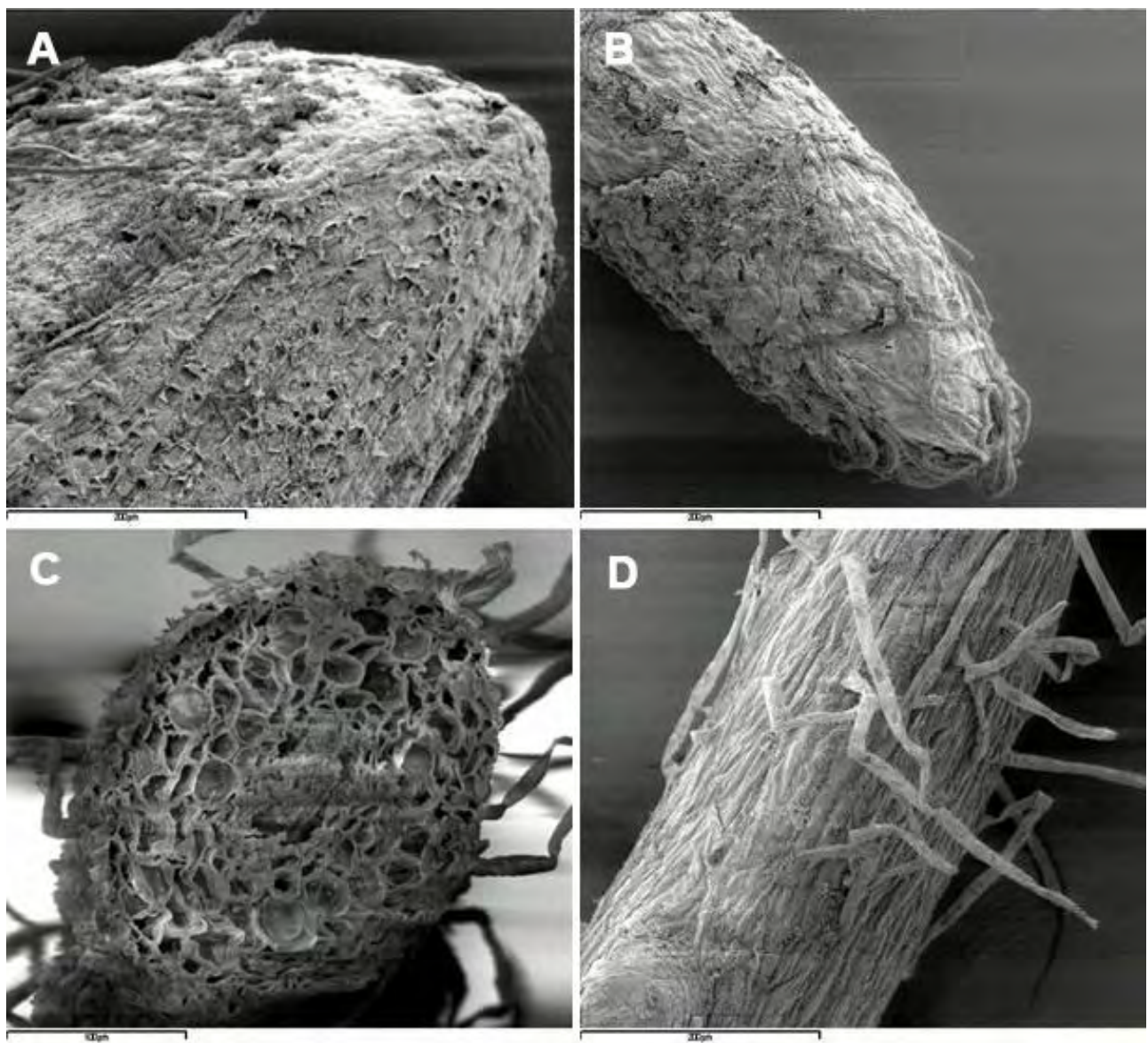
sue necrosis was observed in roots of these poplar clones after the treatment. However, a specific analysis on vessel lumina associated with changes in wall strength in response to metal was not done, and possible effects of $\mathrm{Cd}$ on plant transport system cannot be ruled out. In plants subjected to long-term treatment with $\mathrm{Cd}$, alterations of the root structure might also influence redistribution and accumulation of the metal in different root tissues and/or cell compartments (Wójcik et al. 2005).

In the control treatment the average concentration of $\mathrm{Cd}$ in root tips was below the detection limit of EDXMA. From SEMEDXMA, only $\mathrm{Fe}$ and $\mathrm{P}$ other than Cd concentrations were affected by the treatment (Tab. 1). The presence of metal in the growing solution increased $\mathrm{Cd}$ and Fe concentrations in the root tissues, while decreased that of $\mathrm{P}$, in both clones. Contrasting effects of the treatment on clone $6 \mathrm{~K} 3$ and $14 \mathrm{P} 11$ were observed for $\mathrm{Cu}, \mathrm{K}$ and $\mathrm{S}$. High negative correlation of $\mathrm{Cd}$ concentration with $\mathrm{K}$ (and Ca) concentrations in roots has been observed in alfalfa seedlings (Drazic et al. 2006), indicating competition for the same carrier and suggesting differential responses to $\mathrm{Cd}$ in these poplar clones mediated by $\mathrm{K}$ metabolism. Cadmium might have disturbed plant mineral metabolism, its toxicity inducing changes in the nutrient balance. Indeed, $\mathrm{Cd}$ disrupts iron $(\mathrm{Fe})$ metabolism in plants (Wallace et al. 1992). The occurrence of Cd$\mathrm{Fe}$ interactions is consistent with the finding that changes in thylakoid structure are similar in Cd-treated and Fe-deficient plants (Fodor et al. 1996) including poplar (Sárvári mechanism underlying $\mathrm{Cd}$-induced $\mathrm{Fe}$ deficiency in plants has not been identified, there

Tab. 1 - Effects of Cd treatment on the concentration (SEM-EDXMA) of various elements in root tips of $P$. alba clones (6K3 and 14P11). Values are in weight $\%$, peak/background (Cd in control samples was detected below the instrument threshold); data are the mean ( \pm $\mathrm{SE})$.

\begin{tabular}{|c|c|c|c|c|c|c|c|c|}
\hline Clone & $\begin{array}{l}\text { Treat- } \\
\text { ment }\end{array}$ & Cd & $\mathrm{Cu}$ & $\mathbf{K}$ & $\mathbf{F e}$ & $\mathbf{S}$ & $\mathrm{Ca}$ & $\mathbf{P}$ \\
\hline \multirow[t]{2}{*}{$6 \mathrm{~K} 3$} & $\mathrm{Cd}$ & $\begin{array}{c}1.15 \\
(0.14)\end{array}$ & $\begin{array}{c}0.61 \\
(0.11)\end{array}$ & $\begin{array}{c}0.70 \\
(0.07)\end{array}$ & $\begin{array}{c}1.15 \\
(0.13)\end{array}$ & $\begin{array}{c}2.90 \\
(0.19)\end{array}$ & $\begin{array}{c}1.34 \\
(0.12)\end{array}$ & $\begin{array}{c}2.93 \\
(0.15)\end{array}$ \\
\hline & Control & $<5 \mathrm{mM}$ & $\begin{array}{c}0.00 \\
(0.00)\end{array}$ & $\begin{array}{c}0.34 \\
(0.06)\end{array}$ & $\begin{array}{c}0.10 \\
(0.10)\end{array}$ & $\begin{array}{c}1.49 \\
(0.01)\end{array}$ & $\begin{array}{c}0.74 \\
(0.18)\end{array}$ & $\begin{array}{c}3.84 \\
(0.42)\end{array}$ \\
\hline \multirow[t]{2}{*}{$14 \mathrm{P} 11$} & $\mathrm{Cd}$ & $\begin{array}{c}0.25 \\
(0.07)\end{array}$ & $\begin{array}{c}0.31 \\
(0.05)\end{array}$ & $\begin{array}{c}0.12 \\
(0.02)\end{array}$ & $\begin{array}{c}0.16 \\
(0.04)\end{array}$ & $\begin{array}{c}0.84 \\
(0.11)\end{array}$ & $\begin{array}{c}0.48 \\
(0.10)\end{array}$ & $\begin{array}{c}1.27 \\
(0.17)\end{array}$ \\
\hline & Control & $<5 \mathrm{mM}$ & $\begin{array}{c}0.75 \\
(0.25)\end{array}$ & $\begin{array}{c}0.62 \\
(0.14) \\
\end{array}$ & $\begin{array}{c}0.08 \\
(0.04) \\
\end{array}$ & $\begin{array}{c}1.97 \\
(0.31)\end{array}$ & $\begin{array}{c}0.38 \\
(0.05)\end{array}$ & $\begin{array}{c}3.34 \\
(0.28)\end{array}$ \\
\hline \multicolumn{9}{|c|}{ ANOVA $(P)$} \\
\hline one & - & 0.1606 & 0.3786 & 0.3028 & 0.0564 & 0.0947 & 0.0986 & 0.0545 \\
\hline treatment & - & 0.0317 & 0.7343 & 0.6748 & 0.0326 & 0.7677 & 0.3465 & 0.0088 \\
\hline interaction & - & 0.1606 & 0.0396 & 0.0035 & 0.0675 & 0.0073 & 0.4895 & 0.2983 \\
\hline
\end{tabular}
et al. 2000, Sárvári et al. 2001). Although the

are several possible explanations. The root Fe-deficiency-inducible enzyme Fe(III)-chelate reductase is inhibited by Cd (Alcántara et al. 1994), suggesting that Cd may directly impair Fe acquisition. Also, Cd, which usually accumulates in roots (Simon 1998, Zhang et al. 2000), almost completely inhibits $\mathrm{Fe}$ translocation from roots to shoots, leading to increase root $\mathrm{Fe}$ concentrations in cucumber (Fodor et al. 1996) and mung bean (Liu et al. 2000). Once in the apoplast, Cd may compete with other divalent metal ions such as $\mathrm{Ca}^{2+}, \mathrm{Zn}^{2+}$ and $\mathrm{Fe}^{2+}$ for binding sites and transport mechanisms (Clemens 2001).

Differences between clones in the concentration of metal and nutrients at the apex, and between 0.5 and $1 \mathrm{~cm}$ (median) and at $2 \mathrm{~cm}$ (section) from the apex of root samples were

Tab. 2 - Concentrations (SEM-EDXMA) of various elements in root tips of P. alba clones (6K3 and 14P11) subjected to $\mathrm{Cd} 40 \mu \mathrm{M}$, sampled at the apex, and between 0.5 and $1 \mathrm{~cm}$ (median) and at $2 \mathrm{~cm}$ (section) from the apex. Values are in weight $\%$, peak/background; data are the mean $( \pm \mathrm{SE})$.

\begin{tabular}{ccccccccc}
\hline Clone & Position & $\mathbf{C d}$ & $\mathbf{C u}$ & $\mathbf{K}$ & $\mathbf{F e}$ & $\mathbf{S}$ & $\mathbf{C a}$ & $\mathbf{P}$ \\
\hline 6K3 & apex & 1.52 & 0.86 & 0.90 & 1.71 & 2.62 & 1.73 & 2.96 \\
& & $(0.27)$ & $(0.21)$ & $(0.12)$ & $(0.22)$ & $(0.30)$ & $(0.23)$ & $(0.22)$ \\
& \multirow{2}{*}{ median } & 0.94 & 0.65 & 0.71 & 1.09 & 3.18 & 1.37 & 2.69 \\
& & $(0.19)$ & $(0.18)$ & $(0.11)$ & $(0.18)$ & $(0.38)$ & $(0.21)$ & $(0.09)$ \\
& \multirow{2}{*}{ section } & 0.96 & 0.27 & 0.47 & 0.56 & 2.91 & 0.85 & 3.18 \\
& & $(0.21)$ & $(0.11)$ & $(0.12)$ & $(0.16)$ & $(0.30)$ & $(0.14)$ & $(0.42)$ \\
$14 \mathrm{P} 11$ & \multirow{2}{*}{ apex } & 0.08 & 0.25 & 0.07 & 0.03 & 0.42 & 0.16 & 0.59 \\
& & $(0.04)$ & $(0.08)$ & $(0.03)$ & $(0.02)$ & $(0.12)$ & $(0.04)$ & $(0.16)$ \\
& \multirow{2}{*}{ median } & 0.47 & 0.44 & 0.18 & 0.32 & 1.28 & 0.87 & 2.00 \\
& & $(0.15)$ & $(0.08)$ & $(0.03)$ & $(0.09)$ & $(0.17)$ & $(0.21)$ & $(0.28)$ \\
& \multirow{2}{*}{ section } & 0.02 & 0.06 & 0.12 & 0.08 & 0.69 & 0.18 & 1.06 \\
& & $(0.02)$ & $(0.06)$ & $(0.07)$ & $(0.05)$ & $(0.32)$ & $(0.08)$ & $(0.42)$ \\
\hline
\end{tabular}

ANOVA $(P)$

\begin{tabular}{llccccccc}
\hline clone & - & $<0.0001$ & 0.0026 & $<0.0001<0.0001<0.0001$ & $<0.0001$ & $<0.0001$ \\
position & - & 0.2566 & 0.0157 & 0.0683 & 0.0008 & 0.0090 & 0.0155 & 0.0959 \\
interaction & - & 0.0095 & 0.2038 & 0.0099 & $<0.0001$ & 0.7495 & 0.0060 & 0.0042
\end{tabular}

always consistent (Tab. 2; SEM-EDXMA). In general, differences between clones were evident for the position of preferential metal and nutrients accumulation, which was the apex for clone $6 \mathrm{~K} 3$ and in the range $0.5-1$ $\mathrm{cm}$ from the apex for clone 14P11. The potential for enormous genetic variation of poplar is promising for selecting clones of local germplasm collections with a high capacity for phytoextraction of specific heavy metals from soils or waters. These poplar clones are currently studied for determining physiological and morphological parameters in plants exposed to toxic concentrations of Cd solution, as well as, their ability to accumulate $\mathrm{Cd}$ in roots and to translocate it to leaves (CNR-IBAF, Montelibretti, Italy). Again, they are also under genetic analysis by selecting genes involved in the different steps of the process for Cd uptake, sequestration, compartmentalisation, and translocation, which will eventually help in identifying possible molecular descriptors of plant performance for phytoremediation (Università della Tuscia, Viterbo, Italy).

Overall, the SEM-EDXMA showed a higher capacity of $\mathrm{Cd}$ accumulation in clone $6 \mathrm{~K} 3$ than clone 14P11. Clonal differences in the aptitude of metal accumulation were, however, not supported by the chemical analysis (Tab. 3). These methodological discrep-

Tab. 3 - Concentration and content of $\mathrm{Cd}$ in the root system of $P$. alba clones $(6 \mathrm{~K} 3$ and 14P11) determined by atomic absorption spectrophotometry. Data are the mean $( \pm$ $\mathrm{SE})$; $t$-test comparison between clones is also reported.

\begin{tabular}{ccc}
\hline Clone & $\begin{array}{c}\text { Cd concentration } \\
(\mathbf{m g} / \mathbf{k g})\end{array}$ & $\begin{array}{c}\text { Cd content } \\
(\mathbf{m g} \text { per root) }\end{array}$ \\
\hline $6 \mathrm{~K} 3$ & $6089(1068) \mathrm{ns}$ & $1.91(0.46) \mathrm{ns}$ \\
$14 \mathrm{P} 11$ & $7964(944) \mathrm{ns}$ & $4.71(1.18) \mathrm{ns}$ \\
\hline
\end{tabular}




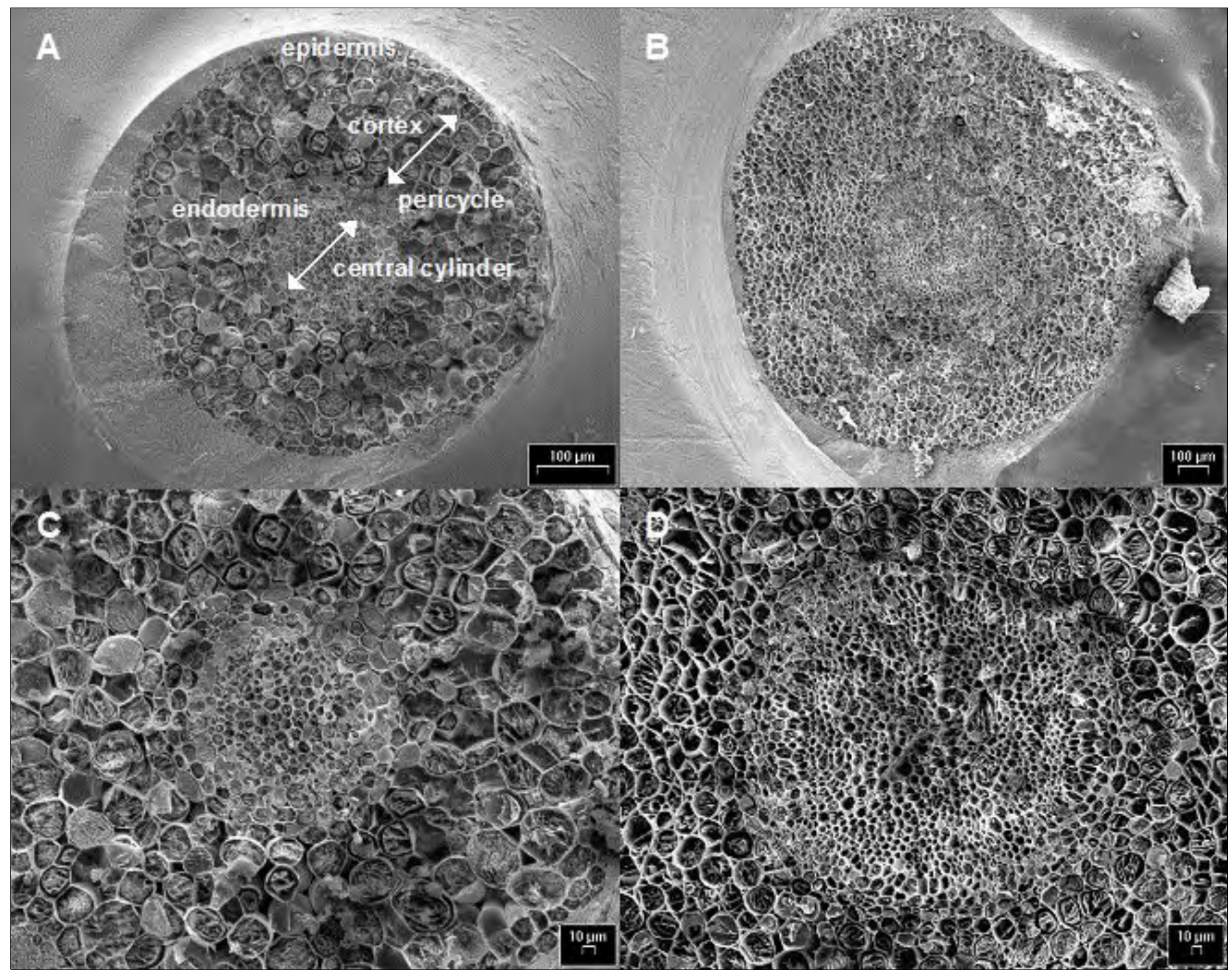

Fig. 3 - Cryo-scanning electron micrographs of poplar root cross-sections: A and C, clone 14P11; B and D clone 6 K3.

ancies might be only apparent and due to the scattered scenery of EDXMA when mapping a localized portion of the root compared to the complete sampling of the root while performing the chemical analysis. In turn, this behaviour might highlight differences in the translocation capacity between clones; clone $14 \mathrm{P} 11$ being more efficient than clone $6 \mathrm{~K} 3$ in the translocation process of metal and nutrients from roots to the stem. A delay in $\mathrm{Cd}$ transport through membranes inside cells might represent, according to Nedelkoska \& Doran (2000), an important defence mechanism against metal poisoning, enabling simultaneous activation of intracellular detoxification mechanisms of $\mathrm{Cd}$.

Cryo-SEM images of frozen-hydrated transversally freeze-fractured young poplar roots did not show, in both clones, any damage to the whole root structure, such as shrinkage or collapse (Fig. 3A and C). In particular, central cylinder and endodermis in roots of both clones showed perfectly pre- served cells (Fig. 3B and D). Differences between treatments were found somewhat in the number of cell rows of these two tissues (data not shown). Living, constantly growing root fragments were sampled for analysis, and the preparation procedure did not cause injure of tissues. Therefore, we may conclude that the main transport system was not impaired at the root level in these poplar clones. Nevertheless, changes in cell structure might appear after longer time of exposure to $\mathrm{Cd}$ and at higher concentrations of the metal (Seregin \& Ivanov 1997). Increasing amounts of $\mathrm{Cd}$ penetrating deeper into the root as well as inside cells may be expected in this latter case, suggesting that the cell wall might be the first barrier protecting the protoplast from $\mathrm{Cd}$ toxic action, and $\mathrm{Cd}$ binding to the cell wall might be an important mechanism of tolerance to this metal, especially at low to medium concentrations and short time of exposure (from several days up to a few weeks).
The poplar root accumulated so much $\mathrm{Cd}$ that the peak/background ratio was high enough for recording dot-maps of metal distribution (Fig. 4; Cryo-SEM-EDXMA). In our experiment, $\mathrm{Cd}$ accumulated in different root tissues - in parenchyma cells of cortex, in the endodermis, in parenchyma cells of central cylinder and in xylem vessels. However, compared with other important ions (e.g., $\mathrm{Ca}$, showing a rather diffuse allocation), the distribution of $\mathrm{Cd}$ within the root (similar to that of $\mathrm{K}$ ) was preferentially localized in the surroundings of central cylinder. Many studies have shown that the main site of Cd accumulation in roots is the apoplast, particularly cell walls (Wójcik et al. 2005). Khan et al. (1984) and LozanoRodríguez et al. (1997) found that in maize roots the metal was mainly detected in cell walls of cortex parenchyma, endodermis and pericycle, while much smaller amounts were found in protoplasts. These results are contradictory with those of Rauser \& Ackerley 
(1987) who did not find Cd in cell walls of maize and Agrostis roots. Instead, $\mathrm{Cd}$ was located in electron-dense granules in the cytoplasm and in vacuoles of differentiating and mature cells and in nuclei of undifferentiated cells. Similarly, Vázquez et al. (1992b) showed the presence of $\mathrm{Cd}$ in the vacuole and nuclei but not in cell walls, cytoplasm and plastids of bean roots.

Nevertheless, a privileged accumulation of $\mathrm{Cd}$ in cell walls of poplar roots was confirmed by ambient-SEM-EDXMA observations (Fig. 5A, B). The dot-map of metal distribution also evidenced that $\mathrm{Cd}$ within the root was preferentially localized in the surroundings of central cylinder. The importance of $\mathrm{Cd}$ binding to cell walls and the limitation of its subsequent translocation to shoots has been demonstrated for root cells of non-hyperaccumulating plants (Wagner 1993, Grant et al. 1998) and was recently described for Thlaspi caerulescens hairy roots (Boominathan \& Doran 2003). Some authors suggest that in roots, the capacity to bind $\mathrm{Cd}$ in the cell wall has a protective action against the deleterious effect of $\mathrm{Cd}$ by reducing the amounts of cytosolic Cd (LozanoRodríguez et al. 1997, Ramos et al. 2002, Zornoza et al. 2002). Again, Wójcik et al. (2005) and Vögeli-Lange \& Wagner (1990) suggest that the cell wall plays a minor role in $\mathrm{Cd}$ retention in leaves, and the main mechanisms of $\mathrm{Cd}$ detoxification are located inside cells, in vacuoles. Cadmium may induce synthesis of metal binding organic substances for metal detoxification in the cytoplasm (Reese \& Wagner 1987, Weigel \& Jäger 1980). A limitation in ion binding specificity of these compounds would result in increased accumulation of the metal in the root and decreased metal translocation to the shoot (Gussarsson et al. 1995), which may be clone-specific.

Cellular Cd is known to accumulate preferentially within vacuoles, which has often been proposed as a possible mechanism of $\mathrm{Cd}$ tolerance in plants. Although the role of cell walls in Cd binding and storage in plants remains controversial, $\mathrm{Cd}$ was found both inside vacuoles and in cell walls. This latter result was obtained by both ambient-SEMand cryo-SEM-EDXMA observations and compartmental studies and in both clones, indicating an additional storage mechanism. Artefacts and/or Cd losses may occur during the preparation of cell fractions separated by biochemical and physical methods (epidermal strips, protoplast extraction, apoplast wash fluid, and cell wall extraction). In this sense, the cryo-SEM-EDXMA is more reliable, but lack of sensitivity and interference with other elements (e.g., $\mathrm{K})$ impose cautions when using a single approach. Using EDXMA at room temperature may cause redistribution and loss of elements, which lowers the reliability of data obtained with this technique.
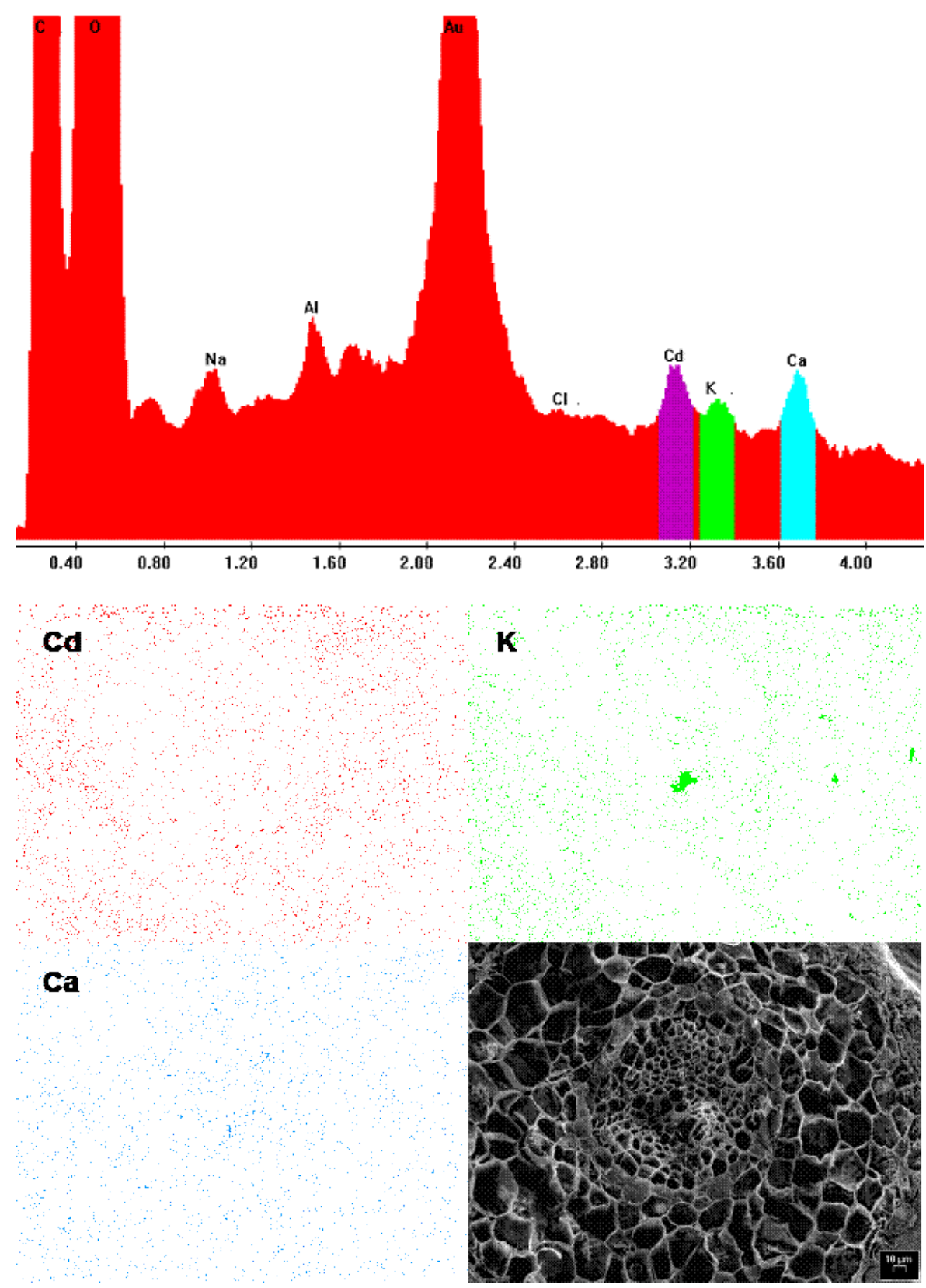

Fig. 4 - EDXMA spectrum obtained by the scanning electron microscope and corresponding dot-map localization of $\mathrm{Cd}$ (red), $\mathrm{K}$ (green) and $\mathrm{Ca}$ (blue) within the root of P. alba.

Large losses of loosely bound $\mathrm{Cd}$ from roots during tissue preparation by conventional fixation for electron microscopy can be partly overcome through cryo-fixation, if the latter is fast enough to retain the original distribution of inorganic elements sufficiently for micro-analytical study (Frey et al. 2000). This method, without the interference of chemical fixative and with no ice crystal damage, allows opportunities to localize elements under conditions closely resembling the natural state, though estimates of metal distribution are qualitative and at a low spatial resolution, unless ultrathin cryo-sections are opportunely prepared and used for quant- itative analysis at subcellular level.

\section{Conclusions}

The present work shows the potential for Cd accumulation in poplar clones. This may be of importance for soil remediation technologies based on metal extraction by plants in phytoremediation. A dissimilar depletion of $\mathrm{Cd}$ in the rhizosphere of these two poplar clones may occur because of differential uptake, and different $\mathrm{Cd}$-induced responses may occur because of interference with other ions. In the root of these poplar clones $\mathrm{Cd}$ might form precipitates with other elements, such as P (Küpper et al. 2000), in the apo- 
Fig. 5 - Ambient temperature scanning electron micrograph of a poplar fractured root cross-section (A) and corresponding dot-map localization of Cd (red) obtained by energy-dispersive $\mathrm{x}$-ray microanalysis (B).
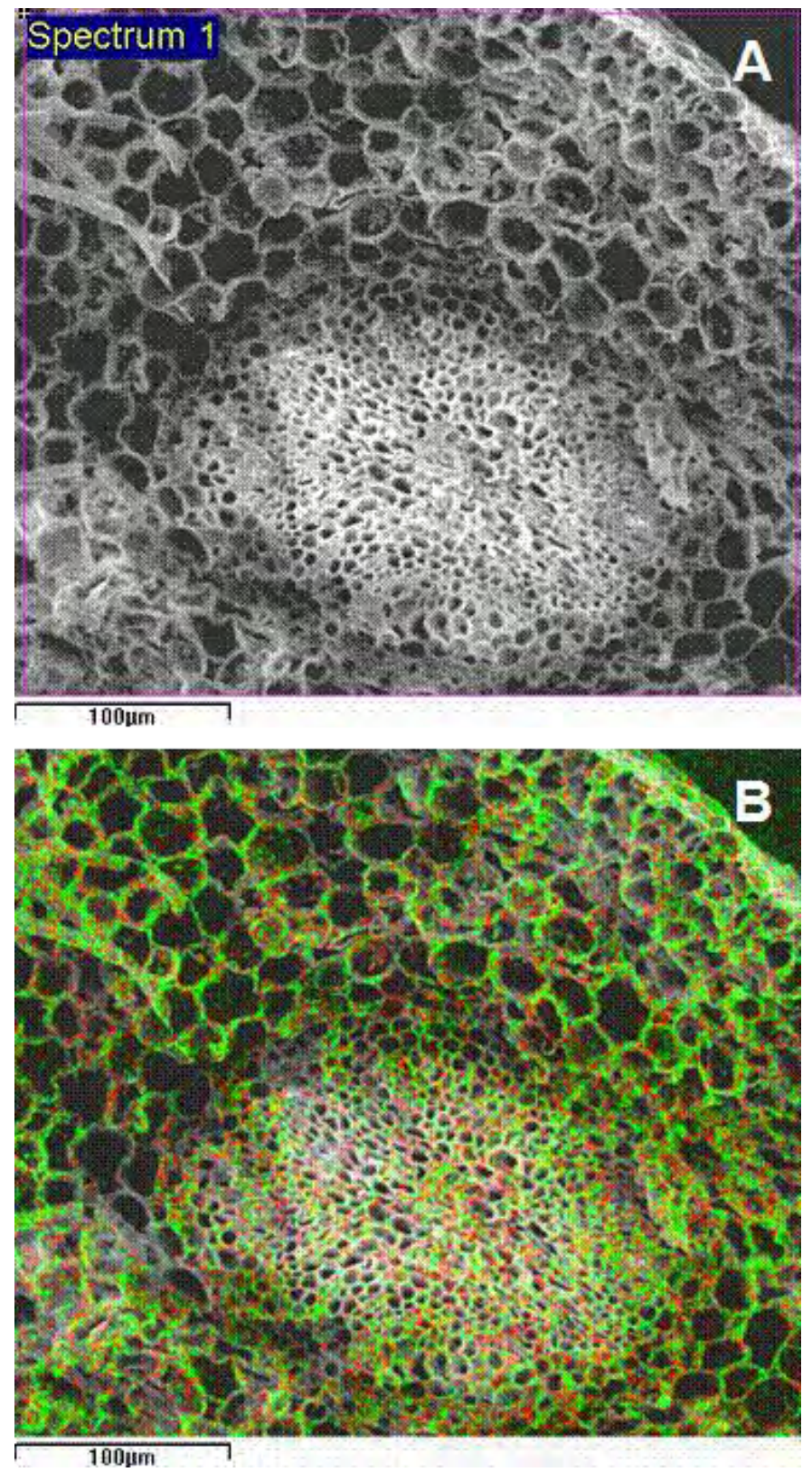

plast of the rhizodermis. The diffuse presence of the metal in cortex parenchyma cells while physiological activity was not impaired points to a decreased $\mathrm{Cd}$ toxicity with constant $\mathrm{Cd}$ content in the growing solution, and in turn suggests Cd storage in minor toxic forms or in cell compartments weakly sensitive to Cd (Carrier et al. 2003). When challenged with heavy metals, plants are known to synthesize chelators (such as phytochelatins) that are able to bind metals, thus reducing the amount of free metals in their cells (Rauser 1999). The role of phytochelatins and their precursor glutathione in shuttling $\mathrm{Cd}$ ions from the cytosol to the vacuole needs to be investigated in these clones. However, the possibility of a higher rate of metal transport into the vacuole through an additional sequestration mechanism deserves further studies in poplars. The results of this study demonstrated the importance of applying multiple methodologies toward a fuller understanding of cellular response to heavy-metal exposure. We believe that only through compound studies one can gain the insight needed to make predictive statements regarding the effect of metal toxicants on different poplar clones.

\section{Acknowledgments}

We acknowledge funding by MUR (PRIN 2005). We are indebted to Lucia Maiuro (CSIM, Università del Molise) for SEM analysis.

\section{References}

Ager FJ, Ynsa MD, Domínguez-Solís JR, Gotor C, Respaldiza MA, Romero LC (2002). Cadmi- um localization and quantification in the plant Arabidopsis thaliana using micro-PIXE. Nuclear Instruments and Methods B 189: 494-498.

Ager FJ, Ynsa MD, Domínguez-Solís JR, LópezMartín MC, Gotor C, Romero LC (2003). Nuclear micro-probe analysis of Arabidopsis thaliana leaves. Nuclear Instruments and Methods B 210: 401-406.

Alcántara E, Romera FJ, Cañete M, de La Guardia MD (1994). Effects of heavy metals on both induction and function of root Fe (III) reductase in Fe-deficient cucumber (Cucumis sativus L.) plants. Journal of Experimental Botany 45: 1893-1898.

Arisi ACM, Mocquot B, Lagriffoul A, Mench M, Foyer CH, Jouanin L (2000). Responses to cadmium in leaves of transformed poplars overexpressing $\gamma$-glutamylcysteine synthetase. Physiologia Plantarum 109: 143-149.

Baker AJM (1981). Accumulators and excluders strategies in the response of plants to heavy metals. Journal of Plant Nutrition 3: 643-654.

Baker AJM, McGrath SP, Reeves RD, Smith JAC (2000). Metal hyperaccumulator plants: a review of the ecology and physiology of a biochemical resource for phytoremediation of metal-polluted soils. In: Phytoremediation of contaminated soil and water (Terry N, Bañuelos G eds). Lewis, Boca Raton, FL, USA, pp. 85-107.

Barceló J, Poschenrieder C (1990). Plant water relation as affected by heavy metal stress: a review. Journal of Plant Nutrition 13: 1-37.

Barceló J, Vazquez MD, Poscenrieder C (1988). Structural and ultrastructural disorders in cadmium-treated bush bean plants (Phaseolus vulgaris L.). New Phytologist 108: 37-49.

Beritognolo I, Piazzai M, Benucci S, Kuzminsky E, Sabatti M, Scarascia Mugnozza G, Muleo R (2007). Functional characterisation of three Italian Populus alba L. genotypes under salinity stress. Trees 21: 465-477.

Boominathan R, Doran PM (2003). Organic acid complexation, heavy metal distribution and the effect of ATPase inhibition in hairy roots of hyperaccumulator plant species. Journal of Biotechnology 101: 131-146.

Borghi M, Tognetti R, Monteforti G, Sebastiani L (2007). Responses of Populus $\times$ euramericana $(P$. deltoides $\times P$. nigra) clone Adda to increasing copper concentrations. Environmental and Experimental Botany 61: 66-73.

Carrier P, Baryla A, Havaux M (2003). Cadmium distribution and microlocalization in oilseed rape (Brassica napus) after long-term growth on cadmium-contaminated soil. Planta 216: 939-950.

Clemens S (2001). Molecular mechanisms of plant metal tolerance and homeostasis. Planta 212: 475-486.

Di Baccio D, Kopriva S, Sebastiani L, Rennenberg $H$ (2005). Does glutathione metabolism have a role in the defence of poplar against zinc excess? New Phytologist 167: 73-80.

Di Baccio D, Tognetti R, Sebastiani L, Vitagliano C (2003). Responses of Populus deltoides $\times$ Populus nigra (Populus $\times$ euramericana) clone I-214 to high zinc concentrations. New Phytologist 
159: 443-452.

Drazic G, Mihailovic N, Lojic M (2006). Cadmium accumulation in Medicago sativa seedlings treated with salicylic acid. Biologia Plantarum 50: 239-244

Fodor F, Gáspár L, Morales F, Gogorcena Y, Lucena JJ, Cseh E, Kröpf K, Abadía J, Sárvári É (2005). Effects of two iron sources on iron and cadmium allocation in poplar (Populus alba) plants exposed to cadmium. Tree Physiology 25:1173-1180.

Fodor F, Sárvári É, Láng F, Szigeti Z, Cseh E (1996). Effects of $\mathrm{Pb}$ and $\mathrm{Cd}$ on cucumber depending on the Fe-complex in the culture solution. Journal of Plant Physiology 148: 434-439.

Frey B, Keller C, Zierold K, Schulin R (2000). Distribution of $\mathrm{Zn}$ in functionally different leaf epidermal cells of the hyperaccumulator Thlaspi caerulescens. Plant, Cell \& Environment 23 . 675-687.

Grant CA, Buckley WT, Bailey LD, Selles F (1998). Cadmium accumulation in crops. Canadian Journal of Plant Science 78: 1-17.

Gussarsson M, Adalsteinsson S, Jensén R, Asp H (1995). Cadmium and copper interactions on the accumulation and distribution of $\mathrm{Cd}$ and $\mathrm{Cu}$ in birch (Betula pendula Roth) seedlings. Plant and Soil 171: 185-187.

Hernández LE, Gárate A, Carpena-Ruiz R (1997). Effects of cadmium on the uptake, distribution and assimilation of nitrate in Pisum sativum. Plant and Soil 189: 97-106.

Khan DH, Duckett JG, Frankland B, Kirkham JB (1984). An X-ray microanalytical study of the distribution of cadmium in roots of Zea mays $\mathrm{L}$. Journal of Plant Physiology 115: 19-28.

Koprivova A, Kopriva S, Jäger D, Will B, Jouanin L, Rennenberg H (2002). Evaluation of transgenic poplar lines overexpressing enzymes of glutathione synthesis for phytoremediation of cadmium. Plant Biology 4: 664-670.

Küpper H, Lombi E., Zhao F-J, McGrath SP (2000). Cellular compartmentation of cadmium and zinc in relation to other elements in the hyperaccumulator Arabidopsis halleri. Planta 212: $75-84$

Lamoreaux RJ, Chaney WR (1977). Growth and water movement in silver maple seedlings affected by cadmium. Journal of Environmental Quality 6: 201-205.

Liu J, Reid RJ, Smith FA (2000). The mechanism of cobalt toxicity in mung beans. Physiologia Plantarum 110: 104-110.

Lozano-Rodríguez E, Hernandez LE, Bonay P, Carpena-Ruiz RO (1997). Distribution of cadmium in shoot and root tissues of maize and pea plants: physiological disturbances. Journal of Experimental Botany 48: 123-128.

Madejón P, Marañon T, Murillo JM, Robinson B (2004). White poplar (Populus alba) as a biomonitor of trace elements in contaminated riparian forests. Environmental Pollution 132: 145-155.

Moffat AJ, Armstrong AT, Ockleston J (2001).
The optimization of sewage sludge and effluent disposal on energy crops of short rotation hybrid poplar. Biomass and Bioenergy 20: 161-169.

Nedelkoska TV, Doran PM (2000). Hyperaccumulation of cadmium by hairy roots of Thlaspi caerulescens. Biotechnology and Bioengineering 67: 607-615.

Punshon T, Dickinson N (1997). Acclimation of Salix to metal stress. New Phytologist 137: 303-314.

Ramos I, Esteban E, Lucena JJ, Gárate A (2002). Cadmium uptake and subcellular distribution in plants of Lactuca sp. Cd-Mn interaction. Plant Science 162: 761-767.

Rauser WE (1999). Structure and function of metal chelators produced by plants. Cell Biochemistry and Biophysics 31: 19-48.

Rauser WE, Ackerley CA (1987). Localization of cadmium in granules within differentiating and mature root cells. Canadian Journal of Botany 65: 643-646.

Reese RN, Wagner GJ (1987). Effects of buthionine sulfoximine on Cd-binding peptide levels in suspension-cultured tobacco cells treated with Cd, Zn, or Cu. Plant Physiology 84: 574-577.

Salt DE, Smith RD, Raskin D (1998). Phytoremediation. Annual Review of Plant Physiology and Plant Molecular Biology 49: 643-668.

Sárvári É, Fodor F, Cseh E, Szigeti Z, Láng F (2000). Comparison of the effects of Cd stress and Fe-deficiency on the thylakoid development in poplar offsprings. Plant Physiology and Biochemistry 38S: 180.

Sárvári É, Szigeti Z, Fodor F, Cseh E, Tussor K, Záray Gy, Veres Sz, Mészáros I (2001). Relationship of iron deficiency and the altered thylakoid development in $\mathrm{Cd}$ treated poplar plants. In Proceedings of 12th Congress on Photosynthesis, S3-25.

Schnoor JL (1999). Phytostabilization of metals using hybrid poplar trees. In: Phytoremediation of toxic metals: using plants to clean up the environment (Raskin I, Ensley BD eds). Wiley-Interscience Publication, New York, NY, USA, pp. 133-150.

Sebastiani L, Scebba F, Tognetti R (2004). Heavy metal accumulation and growth responses in poplar clones Eridano (Populus deltoids $x$ maximowiczii) and I-214 (P. $x$ euramericana) exposed to industrial waste. Environmental and Experimental Botany 52: 79-88.

Seregin IV, Ivanov VB (1997). Histochemical investigation of cadmium and lead distribution in plants. Russian Journal of Plant Physiology 44: 791-796.

Simon L (1998). Cadmium accumulation and distribution in sunflower plants. Journal of Plant Nutrition 21: 341-352.

Sunda WG (1990). Trace metal interactions with marine phytoplankton. Biological Oceanography 6: 411-442.

Surosz W, Palinska KA (2004). Effects of heavy metals stress on cyanobacterium Anabaena flosaquae. Archives of Environmental Contamina- tion and Toxicology 48: 40-48.

Taylor GJ (1987). Exclusion of metals from the symplasm: a possible mechanism of metal tolerance in higher plants. Journal of Plant Nutrition 10: $1213-1222$.

Titov AF, Talanova VV, Boeva NP (1995). Growth responses of barley and wheat seedlings to lead and cadmium. Biologia Plantarum 38: 431-436.

Tognetti R, Sebastiani L, Minnocci A (2004). Gas exchange and foliage characteristics of two poplar clones grown in soil amended with industrial waste. Tree Physiology 24: 75-82.

Van Assche F, Clijsters H (1990). Effects of metals on enzyme activity in plants. Plant Cell \& Environment 13: 195-206.

Vázquez MD, Barceló J, Poschenrieder Ch, Mádico J, Hatton P, Baker AJM, Cope GH (1992a). Localization of zinc and cadmium in Thlaspi caerulescens (Brassicaceae), a metallophyte that can accumulate both metals. Journal of Plant Physiology 140: 350-355.

Vázquez MD, Poschenrieder Ch, Barceló J (1992b). Ultrastructural effects and localization of low cadmium concentrations in bean roots. New Phytologist 120: 215-226.

Vögeli-Lange R, Wagner GJ (1990). Subcellular localization of cadmium and cadmium-binding peptides in tobacco leaves. Plant Physiology 92: 1086-1093.

Vymazal J (1987). Toxicity and accumulation of cadmium with respect to algae and cyanobacteria: A review. Toxicity Assessment 2: 387-415. Wagner GJ (1993). Accumulation of cadmium in crop plants and its consequences to human health. Advances in Agronomy 51: 173-212.

Walker WM, Miller JE, Hassett JJ (1977). Effect of lead and cadmium upon the calcium, magnesium, potassium, and phosphorus concentration in young corn plants. Soil Science 124: 145-151.

Wallace A, Wallace GA, Cha JW (1992). Some modifications in trace metal toxicities and deficiencies in plants resulting from interactions with other elements and chelating agents-the special case of iron. Journal of Plant Nutrition 15 1589-1598.

Weigel HJ, Jäger HJ (1980). Subcellular distribution and chemical form of cadmium in bean plants. Plant Physiology 65: 480-482.

Wójcik M, Vangronsveld J, D’Haen J, Tukiendorf A (2005). Cadmium tolerance in Thlaspi caerulescens. II. Localization of cadmium in Thlaspi caerulescens. Environmental and Experimental Botany 53: 163-171.

Zhang G, Fukami M, Sekimoto H (2000). Genotypic differences in effects of cadmium on growth and nutrient compositions in wheat. Journal of Plant Nutrition 23: 1337-1350.

Zornoza P, Vázquez S, Esteban E, Fernández-Pascual M, Carpena R (2002). Cadmium-stress in nodulated white lupin: strategies to avoid toxicity. Plant Physiology and Biochemistry 40: 1003-1009. 